\title{
Importance of the sugarcane industry in the formal employment in the state of Mato Grosso do Sul during the period of 2008 to 2014
}

\author{
Importância do setor de cana-de-açúcar no emprego formal do estado de \\ Mato Grosso do Sul, durante o período de 2008 a 2014 \\ Lilliane Renata Defante ${ }^{1}$, Olivier François Vilpoux² (1D, Leandro Sauer ${ }^{2}$ \\ ${ }^{1}$ Universidade Católica Dom Bosco de Campo Grande (UCDB), Campo Grande (MS), Brasil. E-mail: lillianerenata@gmail.com \\ ${ }^{2}$ Escola de Administração e Negócios (ESAN), Universidade Federal de Mato Grosso do Sul (UFMS), Campo Grande (MS), Brasil. \\ E-mails: o.vilpoux@gmail.com; leandro.sauer@ufms.br
}

How to cite: Defante, L. R., Vilpoux, O.F., \& Sauer, L. (2020). Importance of the sugarcane industry in the formal employment in the state of Mato Grosso do Sul during the period of 2008 to 2014. Revista de Economia e Sociologia Rural, 58(4), e193496. https://doi.org/10.1590/1806-9479.2020.193496

\begin{abstract}
In the early 2000s, sugarcane experienced high growth in Brazil and Mato Grosso do Sul experienced the highest growth, with a 398\%\% increase. We analysed the impact of the sugarcane industry on formal employment and wages in Mato Grosso do Sul between 2008 and 2014. We used a Normalized Concentration Index ( $\mathrm{nCl}$ ) decomposed into Location Quotient (LQ), modified Hirschman Herfindahl Index (HHm), and Relative Participation (RP). Data were collected in the Annual Report on Social Information (RAIS). The $\mathrm{nCl}$ allows a general perception of concentration since LQ and HHm give greater weight to small municipalities with few activities, and the RP underestimates the importance of industry for these same municipalities. Thus, the municipality of Dourados, the second largest in the state, had an RP of 9\%, but low LQ and HHm. The sugarcane industry plays an essential role in the economy of small towns, where it generates most of the formal jobs, with higher salaries. However, the impact is concentrated in a few small cities. Another effect is the fast disappearance of the benefits of the sugarcane industry in areas where processing units were closed. The dependence of the sugarcane industry in small municipalities is a concern whose solution should be further studied.
\end{abstract}

Keywords: spatial concentration, concentration index, rural development.

Resumo: No início de 2000, a cana-de-açúcar cresceu muito no Brasil e o estado do Mato Grosso do Sul obteve a maior taxa de crescimento, com 398\%. Foi avaliado o impacto da indústria de cana-de-açúcar no emprego formal e nos salários desse estado entre 2008 e 2014. Foi utilizado o Índice de Concentração Normalizada $(\mathrm{nCl})$ decomposto em Quociente de Localização (LQ), Índice Hirschman Herfindahl modificado (HHm) e Participação Relativa (RP). Os dados foram coletados no Relatório Anual de Informações Sociais (RAIS). O nCl permite uma percepção geral da concentração, pois LQ e $\mathrm{HHm}$ conferem um peso maior para municípios pequenos, com poucas atividades, enquanto a RP subestima a importância do setor nesses mesmos municípios. Assim, o município de Dourados, segundo maior do estado, possuía RP de 9\% em 2014, mas baixos LQ e HHm. A indústria da cana-de-açúcar desempenha papel essencial na economia das pequenas cidades, onde gera a maioria dos empregos e salários altos. No entanto, o impacto concentra-se em algumas cidades pequenas. Outro efeito foi o rápido desaparecimento dos benefícios da indústria de cana-de-açúcar onde as unidades de processamento fecharam. A dependência dos pequenos municípios no setor sucroalcooleiro é uma preocupação cujas soluções deverão ser mais estudadas.

Palavras-chave: concentração espacial, índice de concentração, desenvolvimento rural. 


\section{Introduction}

Agriculture and livestock farming have faced great challenges across the globe since the beginning of the twenty-first century. Key obstacles have included population growth, rapid changes in food consumption patterns, the scarcity of natural resources, environmental degradation, and climate change.

In an FAO working paper, Alexandratos \& Bruinsma (2012) reported that it will be necessary to increase food production to meet the projected population growth from seven billion people in 2014 to 9.5 billion in 2050. Increased food demand is accompanied by another challenge: a lack of new land available for cultivation. In addition to the need to produce more in the same space, producers will face new challenges, like climate change, which introduces concerns about energy consumption and an increasing need for renewable energies, part of which can be produced from agricultural raw materials.

Among the main crops used for energy production, sugarcane can be highlighted because of its great historical importance in Brazil. The country is the largest producer of sugarcane in the world and the second-largest producer of ethanol. In 2003, the introduction of flex-fuel cars, fuelled by gasoline, alcohol, or a mixture of both, has allowed the revitalization of the sugarcane industry (Popp et al., 2014; Goldemberg, 2008). Great international interest in ethanol has motivated production facilities, which have increased their production. However, these producers were surprised by the 2008 international crisis, which reflected the slowdown in the sector (Cezarino \& Liboni, 2012). After 2008, some companies closed; however, the sector is still considered one of the most important in Brazilian agriculture.

Brazil produced $39.1 \%$ of world sugarcane in 2014 , followed by India, with $18.7 \%$, China, with 6.7\%, and Thailand, with 5.5\% (Food and Agriculture Organization of the United Nations, 2016). Brazilian sugarcane agribusiness has played an important role in the country's development, generating jobs and income (Oliveira et al., 2014; Neves et al., 2010, 2016). According to the Brazilian Sugarcane Industry Association (União da Industria de Cana de Açúcar, 2015), the sugarcane industry generated more than one million direct jobs in Brazil in 2015. During that year, the sugarcane industry accounted for approximately $4 \%$ of the Brazilian Gross Domestic Product (GDP). Sugarcane production occurs in more than 1,000 municipalities in the country, and in 2016, four states comprised more than $80 \%$ of national production: São Paulo produced 56.2\%; Goias 10.4\%; Minas Gerais 9\%; and Mato Grosso do Sul 7.1\% (Companhia Nacional de Abastecimento, 2016a).

Mato Grosso do Sul, a state in midwestern Brazil deserves to be highlighted because between 2005 and 2014, the planted area of sugarcane expanded by more than 550,000 hectares, a growth of almost $400 \%$. During this period, the expansion of sugarcane in Brazil was 54\% (Companhia Nacional de Abastecimento, 2016b).

According to Garcia (2014), the rural labor market in Brazil underwent major changes from the second half of the 1990s. The author explains these transformations from the modernization of agriculture, a modernization that was particularly important in the sugarcane industry due to the mechanization of harvest. Among the consequences of this evolution, it is possible to mention the increase of formality and qualification of labor in agriculture, with direct repercussions in the level of wages.

In parallel, the growth of sugarcane production as a result of the introduction of flex-fuel cars and the international interest in biofuels (Belik et al., 2013) led companies to search for new areas with a vocation for this activity, which favored the expansion of production in Mato Grosso do Sul.

Based on the recent evolution of the sugarcane industry, with impacts on formal jobs and the level of wages, and due to the growth of this sector in Mato Grosso do Sul, the objective of this research was to analyze the impact of sugarcane on formal employment and wages between 2008 and 2014 in Mato Grosso do Sul. For this, we evaluated the indices of concentration of formal jobs and wages in the sugarcane industry for the different municipalities of the state.

In 2014, the industrialization of sugarcane generated approximately 30,000 direct jobs in Mato Grosso do Sul (Associação de Produtores de Bioenergia de Mato Grosso do Sul, 
2015) and 120,000 indirect jobs (Resende, 2016). This number is very relevant for Mato Grosso do Sul, since, according to the General Register of Employed and Unemployed Workers (Brasil, 2015a), the state employed a total of 577,464 workers in 2014.

The technological development of agriculture in Brazil has been intensifying since the Green Revolution. In the case of sugarcane, planting and harvesting operations have been mechanized and the labor force became smaller compared to other crops (Walter et al., 2014). In 2013, Mato Grosso do Sul had the highest rate of sugarcane mechanization in the country, with $93.4 \%$ of the harvested area. By 2015, approximately $97 \%$ of the state's sugarcane plantations employed mechanized harvesting (Vital, 2015). With these technological changes, the employment profile has also changed, resulting in a reduced volume of labor and an increase in the quality of jobs (Garcia, 2014).

In the following Session, the general context of the sugarcane industry in Mato Grosso do Sul is presented. Then, we present the methodology, followed by results, discussion, and final considerations.

\section{Sugarcane industry in Mato Grosso do Sul}

Over the past decade, the sugarcane area has expanded considerably in Brazil, mainly due to the use of areas occupied with other crops. This evolution can be explained by increased ethanol and sugar consumption (Walter et al., 2014). From 2003, the construction of new plants was driven by the growth of sugar demand in the international market and the significant increase of ethanol use in the country with the arrival of flexible-fuel cars (Gallardo \& Bond, 2011).

Production in Mato Grosso do Sul benefited from the fact that traditional states such as São Paulo, Minas Gerais, and Paraná experienced a shortage of available land for the expansion of sugarcane and high rental and purchase prices for land (Centenaro, 2012). In the early 2000s, with the advent of the flex-fuel car and the growing international interest in biofuels, new areas were opened, and new plants built in regions with a vocation for sugarcane activity (Belik et al., 2013). These changes benefited the state of Mato Grosso do Sul, where the growth of the planted area of sugarcane was great (Figure 1). According to data from UNICA (União da Industria de Cana de Açúcar, 2016), in 2005, the planted area was 136,803 hectares. In 2015 , the area reached 692,300 hectares, an increase of $406 \%$.

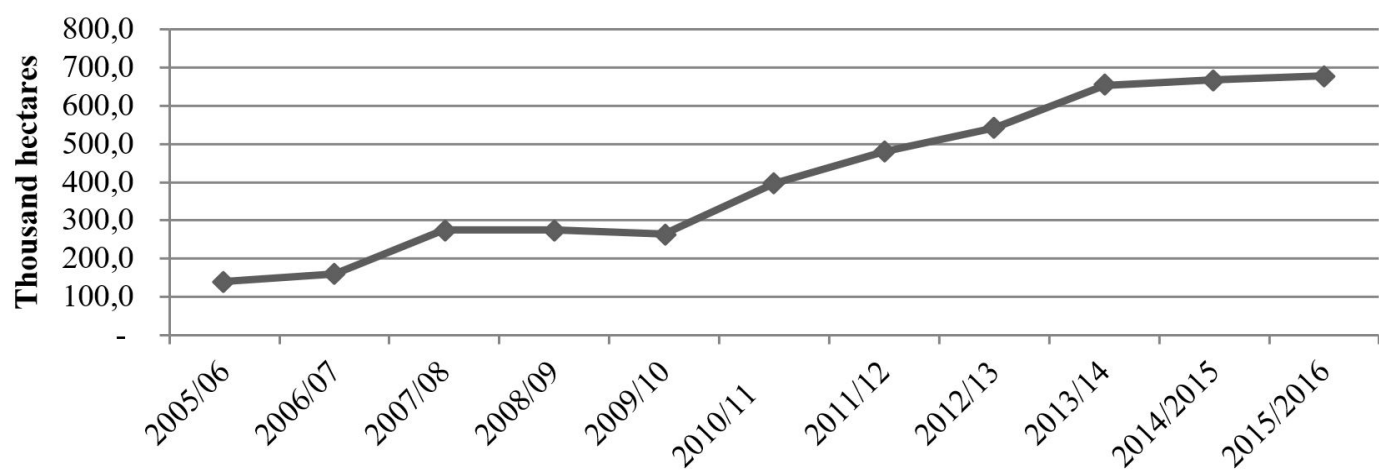

Figure 1 - Evolution of the sugarcane planted area in Mato Grosso do Sul between 2005 and 2015. Source: UNICA (União da Industria de Cana de Açúcar, 2016).

The municipality with the largest planted area of sugarcane in the state is Rio Brilhante, with $12 \%$ of the state area, followed by Nova Alvorada do Sul with $11.4 \%$. Figure 2 shows the evolution of the area by the municipality, between 2004 and 2014. In addition to the growth of the area in the municipalities that already planted sugarcane in 2004, Figure 2 indicates an increase in the number of municipalities with this crop, except in the Pantanal region, where cultivation is prohibited. 


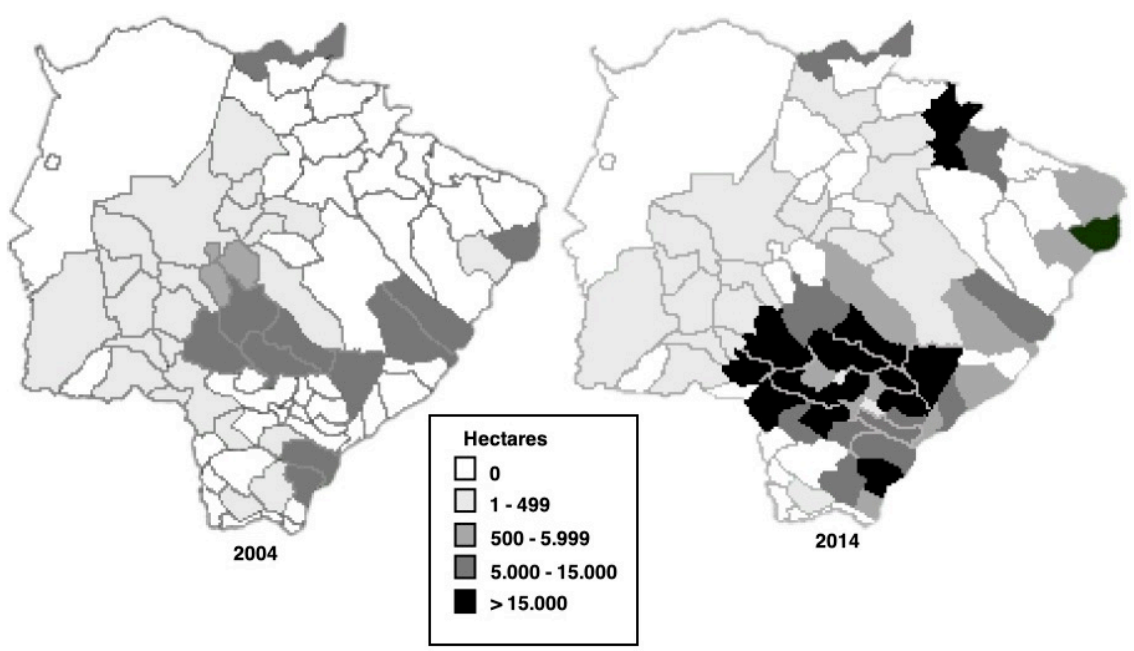

Figure 2 - Main municipalities producing sugarcane in Mato Grosso do Sul, in hectares, in 2004 and 2014. Source: Prepared by the authors based on IBGE data (Instituto Brasileiro de Geografia e Estatística, 2016).

In the 2015/16 harvest, $77.6 \%$ of sugarcane produced in Mato Grosso do Sul was processed for ethanol production (Companhia Nacional de Abastecimento, 2016b). The central, northern, and southern regions of the state experienced a high increase in the sugarcane area, mostly due to new facilities installed before 2009.

Mato Grosso do Sul began to stand out as a producer of sugarcane in the 1970s, with essential support from Proálcool, a political support program. Production started to increase in the 2000s, and after 2006, the state experienced an increase from ten to 22 plants in operation, which had an impact on the formal and informal jobs available in the state (Associação de Produtores de Bioenergia de Mato Grosso do Sul, 2015) (Figure 3).

The global financial crisis of 2008 and stagnant prices of gasoline imposed by the Federal Government had serious consequences for the sugarcane industry. The lack of renewal of cane fields, debt, plant closings, requests for judicial recovery, and low ethanol competitiveness were some of these consequences (Wilkinson, 2015). During this period, there was a stagnation in the development of many new plants in the state of Mato Grosso do Sul. Thus, from 2010, the sugarcane area only increased because of the plants already in operation (Mendonça et al., 2012).

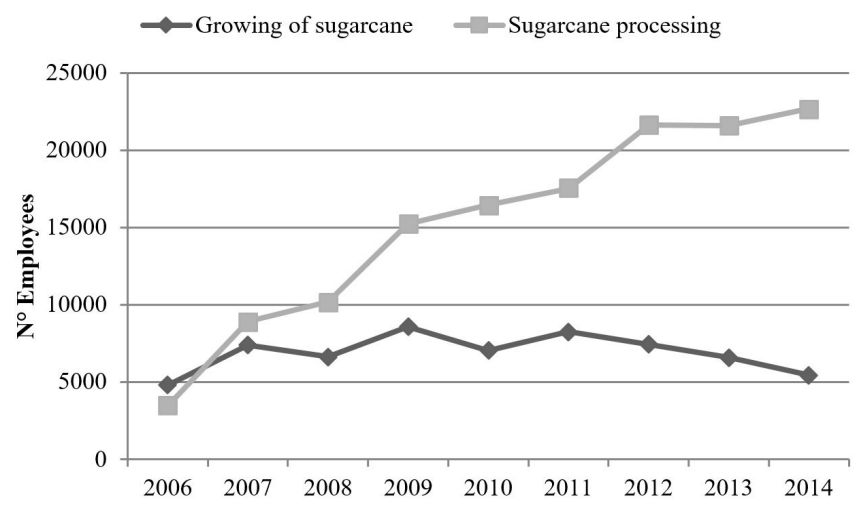

Figure 3 - Evolution of formal employment in the sugarcane agroindustry of Mato Grosso do Sul. Source: adapted from MTE (Brasil, 2015b).

As indicated in Figure 3, from 2006 to 2014 formal employment in the sugarcane industry experienced great changes, with growth in the industrial sector due to the entry of new production facilities and stability in the agricultural sector. The stabilization of formal employment in the agricultural sector occurred even in the face of growth in the planted area, which increased from 160,000 hectares to 670,000 hectares in the same period (Figure 1). 
Vian (2002, 2006), Vian \& Belik (2003), Moraes (2007) and Baccarin et al. (2011) estimated that the creation of skilled jobs with the mechanization of the sugarcane harvest would not be sufficient to maintain the level of employment in agriculture, generating the need to implement policies to facilitate the absorption of unskilled people.

Based on information for the state of São Paulo, Vian (2002) estimated that the total mechanization of sugarcane harvesting would lead to a decrease of $46 \%$ compared to 1999 employment levels. However, in later observations, Toneto Junior \& Liboni (2008) did not verify this decrease. The authors explained the maintenance of employment in agriculture labor due to the growth of the sugarcane industry, which counterbalanced the reduction with mechanization, a situation similar to Mato Grosso do Sul. Vieira (2007) already considered the positive impacts of the expansion of the sugarcane industry despite the reduction of unskilled labor in the harvest due to mechanization. They estimated that 1.3 million direct and indirect jobs could be created, as well as the improvement in the quality of these jobs.

Figure 4 shows the evolution of the formal labor force employed in the sugarcane agroindustry for every 100,000 tons of sugarcane produced by the agricultural sector and processed in the industrial sector. This figure verifies the influence of modernization.

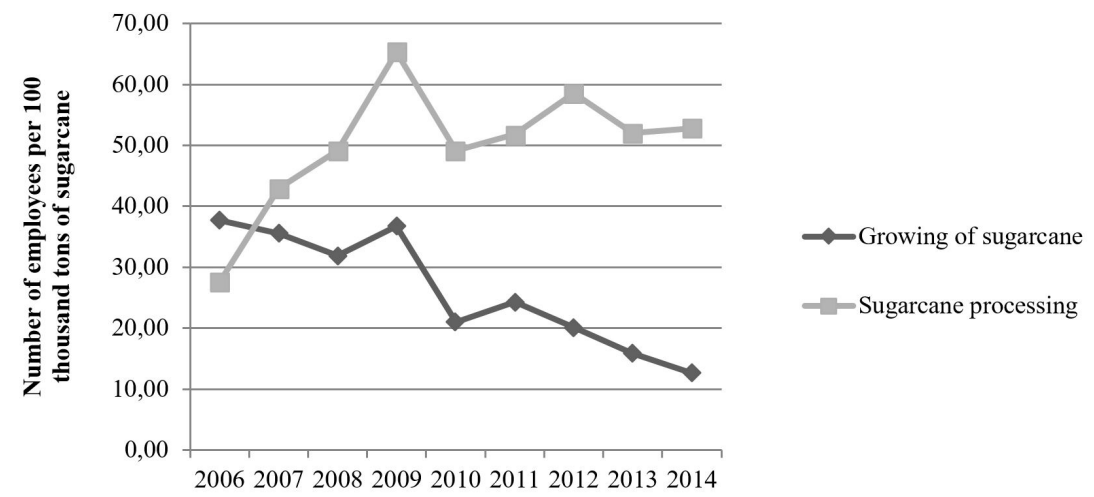

Figure 4 - Evolution of the labor force in the sugarcane industry in Mato Grosso do Sul, for every 100 thousand tons of sugarcane produced or processed

The number of formal jobs per ton of sugarcane produced passed through a continuous reduction in the state during the evaluated period. This evolution can be explained by the increase in harvest mechanization. Waack \& Neves (1998) predicted savings of about $30 \%$ with mechanical harvesting, as well as environmental benefits.

However, the effects of mechanization were limited in Mato Grosso do Sul. According to personal communication of Biosul president, the mechanization rate increased from $82 \%$ in 2010 to $98 \%$ in 2015, whereas in the same period, the number of employees per ton of cane produced decreased by almost 50\%. For Belik et al. (2013), the ability to mechanize was directly linked to the profile of properties and producers. In the more recent regions of sugarcane, such as Mato Grosso do Sul, there are larger properties, owned by the sugarcane mills and with a higher rate of mechanization.

Another factor that may have caused a reduction in agriculture jobs is the general modernization of cultivation. Agricultural modernization was not limited to the mechanization of harvest, but also reached the planting, with the substitution of manual by mechanical planting (Baccarin et al., 2011).

Regarding the processing facilities, there was a growth of formal labor force per ton of processed sugarcane leading up to 2009, when the companies were still in the installation process. In 2010, the sector become more stable in the state and the plants began working at full capacity, which explains the stability of the number of employees per ton of processed cane. Thus, the increase in the total number of employees in the industrial sector, as shown in Figure 3 , is explained by the increase in the production of some processing facilities. 
Baccarin et al. (2011) already showed an increase in the number of people employed in industrial, administrative, and support activities in sugarcane mills and distilleries, following the growth of the sugarcane industry, in contrast to the categories of people employed in agricultural activities with low qualification. Between 2007 and 2009, the authors identified a decrease of $11 \%$ in the number of people employed in agriculture due to the increase in the area of mechanically harvested sugarcane. The number of skilled workers engaged in agricultural mechanization, with a growth of $28 \%$, was insufficient to compensate for the decrease of unskilled workers.

For Moraes (2007) and Garcia (2014), the modernization of agriculture has a strong impact on the rural labor market, not only in the quantity of labor employed but also in its quality. The modernization of agricultural production of sugarcane led to an increase in the demand for skilled labor, which excluded less skilled manual workers. Production per person employed in sugarcane mills and distilleries increased by 29\% between 2007 and 2009. In the same period, the need for unskilled workers for every 1,000 hectares of sugarcane decreased from 57 workers to 40, a reduction of 29\% (Baccarin et al., 2011).

For Vian (2002), in the early 1990s, the Brazilian sugarcane industry was characterized by low wages. However, Vian \& Belik (2003) already identified that the mechanization of harvest could improve the working conditions and wages. At the beginning of the mechanization, Toneto Junior \& Liboni (2008) found a remuneration of people involved in the cultivation of sugarcane $21 \%$ higher than for the average verified in other agricultural activities, and at the same level of soybean, a crop that was, in the period of the results, much more mechanized than sugarcane. The authors concluded that an increase in the mechanization of sugarcane harvest should improve the wages of people working in agricultural activities, surpassing soybean.

This situation was confirmed by Siqueira \& Castro Junior (2013) in a later study, who found better conditions of remuneration and formalization of labor relations, both in agricultural jobs, with a higher remuneration than the average of other agricultural activities, as in the industrial sector, with a remuneration equal to the average of the other food activities. Excluding the Northeast region, Toneto Junior \& Liboni (2008) found a remuneration of sugarcane industrial activities higher than the average of the food industry.

Table 1 shows the relationship between the average salary in the sugarcane industry, considering agriculture and processing, and the average salary of other activities in the state of Mato Grosso do Sul.

Table 1 - Ratio evolution of the average sugarcane industry wages by the average wages of other activities in the main sugarcane producing cities of Mato Grosso do Sul.

$\begin{array}{cccc}\text { Municipalities } & \mathbf{2 0 0 8} & \mathbf{2 0 1 0} & \mathbf{2 0 1 4} \\ \text { Angélica } & 1,38 & 1,39 & 1,90 \\ \text { Aparecida Do Taboado } & 1,49 & 1,52 & 1,53 \\ \text { Bataipora } & 2,16 & 1,49 & 1,32 \\ \text { Caarapó } & 1,17 & 1,42 & 1,11 \\ \text { Chapadão Do Sul } & 1,20 & 1,29 & 1,16 \\ \text { Costa Rica } & 1,35 & 1,39 & 1,65 \\ \text { Dourados } & 1,42 & 1,21 & 1,19 \\ \text { Eldorado } & 1,49 & 1,03 & 1,06 \\ \text { Fatima Do Sul } & 1,34 & 2,11 & 1,58 \\ \text { Maracaju } & 1,31 & 1,52 & 1,48 \\ \text { Naviraí } & 2,12 & 1,47 & 1,39 \\ \text { Nova Alvorada do Sul } & 1,79 & 1,61 & 1,40 \\ \text { Nova Andradina } & 2,23 & 1,63 & 1,46 \\ \text { Ponta Porã } & - & 1,60 & 1,48 \\ \text { Rio Brilhante } & 1,59 & 1,53 & 1,48 \\ \text { Sonora } & 1,05 & 1,02 & 1,21 \\ \text { Vicentina } & - & 1,09 & 1,30\end{array}$

Source: Established by the authors from RAIS data (Brasil, 2016). 
As indicated in Table 1, in the municipalities that produce sugarcane in Mato Grosso do Sul, people employed in the sugarcane industry receive higher wages than those employed in other activities.

This information contrasts with the sugarcane industry before the mechanization of the sugarcane harvest when the contracted labor force was poorly qualified and paid essentially for productivity (Garcia, 2014).

\section{Methodology}

At first, the methodology presents the origin of the data used in the research, followed by the presentation of concentration indices.

\subsection{Data source}

The analysis of the impact of the sugarcane agroindustry on formal employment and wages in the state of Mato Grosso do Sul was carried out in 2008, 2010, and 2014. The $\mathrm{nCl}$ was calculated based on the methodology proposed by Crocco et al. (2006) and Brito et al. (2016), for each period (2008, 2010 and 2014).

The periods were selected based on technical reasons. In 2008, the world was in a financial crisis, which had a strong impact on international markets for ethanol and sugar, ending a cycle of expansion for this industry in Brazil. In 2010, there was a strong increase in the mechanization of sugarcane. Finally, 2014 was the most recent period with available data at the time of the survey. During this period, there was a policy of inflation control and artificial maintenance of gasoline prices at low levels. This policy harmed the price of ethanol, a situation that impacted sugarcane companies in Brazil, causing more than 80 facilities to stop operating in 2014 (Wilkinson, 2015).

The number of formal jobs and wages in each municipality in the state from the sugarcane agroindustry was determined using the database of the Annual Report of Social Information - RAIS, prepared by the Ministry of Labor and following Moraes (2007), Toneto Junior \& Liboni (2008), Baccarin et al. (2011) and Belik et al. (2013). Differently of Baccarin et al. (2011), agriculture, alcohol, and sugar productions were evaluated together.

The selected categories were based on the CNAE 2.0 (National Classification of Economic Activity) and followed those already used by Belik et al. (2013):

- Cultivation of sugarcane - 0113-0;

- $\quad$ Sugarcane processing (1931- 4 - manufacture of alcohol + 1071-6 - manufacture of raw sugar + 1072-4 - Manufacture of Refined Sugar);

The RAIS, from which the data were collected, presents only information on the formal employment volume in the sugarcane industry. The "formal" characteristic indicates any link between the employee and employer governed by a legal labor contract (Paiva \& Khan, 2011).

\subsection{Normalized Concentration Index}

Concentration indicators of economic activity have been considered important elements of study since the first research of regional economies, especially by Krugman (1991) and Audretsch \& Feldman (1996). Our research uses the Normalized Concentration Index (nCl), which was suggested and published by Crocco et al. (2006) and Brito et al. (2016) to identify potential productive agglomerations. This index is an analysis of three indicators: Location Quotient (LQ), Herfindahl-Hirschman modified ( $\mathrm{HHm})$, and Relative Participation (RP).

According to Chiang (2009), LQ is an efficient way of determining the concentration of a given industry in a region. The LQ is an important tool for evaluating industrial specialization and the clustering of a particular characteristic within a population (Crawley et al., 2013). Therefore, it is essential to understand the strengths and weaknesses of the area studied (Baer \& Brown, 2006). According to De Propris (2005) and Brito et al. (2016), the LQ formula for a sector i in a municipality j can be expressed as follows: 
$L Q_{i j}=\frac{E_{i j} / E_{j}}{E_{i^{*}} / E_{* *}}$

where

$E_{i j}=$ Total employment of sector $\mathrm{i}$ in municipality $\mathrm{j} ;$

$E_{j}=$ Total employment in municipality j;

$E_{i^{*}}=$ Employment of sector $\mathrm{i}$ in the researched state;

$E_{w *}=$ Total employment in the researched state.

The LQ is a way of quantifying the concentration of an industry in a region relative to a larger geographical area, such as a state or a country (Sentz, 2011). For Crawley et al. (2013), the use of LQ needs the employment of an arbitrary cut-off value that does not need to be 1 , the limit that indicates an above-average proportion of employment in a certain sector of activity in a given region. De Propris (2005) chose a cut-off of 1.25 to identify industrial concentration based on employment density. In our study, we chose a cut-off value of 1 .

Although the LQ is an indicator of extreme utility for the identification of the productive specialization of a region, it only shows evidence in the concentration of an industry in a region through its Relative Participation (RP). We must be care with the interpretation of results because it tends to overestimate the weight of the sectors present in places where the production structure is small and with little diversification (Fingleton et al., 2004).

The other evaluated index, the $\mathrm{HHm}$, is a modification of the Hirschman-Herfindahl Index, which was used by Crocco et al. (2006) and Brito et al. (2016) to capture the weight of a sector's activity in a municipality. Brito et al. (2016) calculated the $\mathrm{HHm}$ for a sector i in a municipality $\mathrm{j}$ from formula 2 as follows:

$H H m_{i j}=\left(E_{i j} / E_{i^{*}}\right)-\left(E_{j} / E_{* *}\right)$

This indicator compares the ratio of the weight of sector $\mathrm{i}$ in municipality $\mathrm{j}\left(E_{i j}\right)$ with the weight of sector $i$ in the surveyed larger region, or state $\left(E_{i^{*}}\right)$ decreased by the total number of jobs in municipality j divided by the total number of jobs in the state.

The $\mathrm{HHm}$ ranges from -1 to 1 and the closer to 1 , the greater the weight of sector $\mathrm{i}$ in municipality $\mathrm{j}$ relative to sector $\mathrm{i}$ in the state.

The last index evaluated was the Relative Participation of a sector $\mathrm{i}$ in a municipality $\mathrm{j}$ (Brito et al., 2016):

$R P_{i j}=\frac{E_{i j}}{E_{i^{*}}}$

where RP is the division of the number of jobs in sector $i$ in a municipality $\mathrm{j}$ by the number of jobs in sector $\mathrm{i}$ in the state *.

The RP ranges from 0 to 1 ; the closer to 1 , the greater the share of municipality $\mathrm{j}$ about sector $\mathrm{i}$.

From these three indicators, the normalized Concentration Index of a sector i within a municipality $\mathrm{j}, n C I_{i j}$, is elaborated according to the following formula:

$n C I_{i j}=\theta_{1} n L Q i j+\theta_{2} n R P i j+\theta_{3} H H m i j$

The letter $\mathrm{n}$ in front of the indices means that they have been normalized. We chose to use a standardization procedure for the three indicators using the normalization of the minimum and maximum to linearly normalize the data between $[0,1]$. The following formula was applied: 


$$
Z_{i}=\frac{\left(X_{i}-\operatorname{Min}_{X_{i}}\right)}{\left(\operatorname{Máx}_{X_{i}}-\operatorname{Min}_{X_{i}}\right)}
$$

To obtain the weights $(\theta)$ of each of the previously defined indices, it is necessary to use a multivariate method, that is, a Principal Component Analysis (PCA). Crocco et al. (2006) developed the method used for the study and Brito et al. (2016) used it.

The PCA was performed using SPSS 22 software, using a Varimax rotation method with Kaiser normalization for each of the 3 matrices constructed for 2008, 2010, and 2014.

The first step consists of obtaining the raw data, identified from a matrix with the initial data (Crocco et al., 2006; Brito et al., 2016). The first row of the matrix refers to the values of the coefficients (LQ, RP, HHm) in municipality 1, referring to sector 1; the second line refers to the values of the coefficients ( $L Q, R P, H H m$ ) for municipality 1 and Sector 2 , line $n$ refers to the values of the coefficients (LQ, RP, HHm) for municipality 1 , referring to sector $\mathrm{n}$. After approaching the $n$ sectors of surveyed activities, the $n+1$ line is related to the values of the coefficients (LQ, RP, HHm) of municipality 2 concerning sector 1 and thus to the last municipality.

After performing the PCA, the explained variance $(\beta$ i) was obtained for each component (Table 2). However, we chose to use the explained variances ( $\beta$ i) with the Varimax rotation method, whose objective is to maximize the variation between the weights of each main component.

Table 2 - Variation explained by the main components obtained from the initial matrix.

\begin{tabular}{ccc} 
Component & $\begin{array}{c}\text { Variance explained by the } \\
\text { rotational sums of squared } \\
\text { loads }\end{array}$ & $\begin{array}{c}\text { Total explained } \\
\text { variance }\end{array}$ \\
1 & $\beta_{1}$ & $\beta_{1}$ \\
2 & $\beta_{2}$ & $\beta_{1+} \beta_{2}$ \\
3 & $\beta_{3}$ & $\beta_{1+} \beta_{2}+\beta_{3}(=100 \%)$ \\
\hline
\end{tabular}

Source: Crocco et al. (2006).

The analysis also provides the coefficients $\left(a_{i j}\right.$, with $i$ and $j$ ranging from 1 to 3 ) for each of the three eigenvectors (Table 3 ). These coefficients allow calculating the relative participation of each of the indicators in each of the components, and to understand the importance of these indicators in the components (Crocco et al., 2006).

Table 3 - Matrix of coefficients or eigenvectors of the rotating component matrix.

\begin{tabular}{cccc} 
Input indicator & Component 1 & Component 2 & Component 3 \\
LQ & $\alpha_{11}$ & $\alpha_{12}$ & $\alpha_{13}$ \\
RP & $\alpha_{21}$ & $\alpha_{22}$ & $\alpha_{23}$ \\
HHm & $\alpha_{31}$ & $\alpha_{32}$ & $\alpha_{33}$ \\
\hline
\end{tabular}

Source: Crocco et al. (2006).

To calculate the relative participation of the indicators we need to calculate the value of each component (Ci). For that, as mentioned in Crocco et al. (2006), the coefficient of each indicator for each component is added as indicated in Equations 6, 7 and 8.

$$
\begin{aligned}
& \left|\alpha_{11}\right|+\left|\alpha_{21}\right|+\left|\alpha_{31}\right|=C_{I} \\
& \left|\alpha_{12}\right|+\left|\alpha_{22}\right|+\left|\alpha_{32}\right|=C_{2}
\end{aligned}
$$


$\left|\alpha_{13}\right|+\left|\alpha_{23}\right|+\left|\alpha_{33}\right|=C_{3}$

Finally, the relative participation of the indicators is calculated by dividing the coefficient of each indicator for each component $\left(a_{i j}\right)$ by Ci (Table 4$)$.

Table 4 - Relative participation of the indicators in each of the computed components.

\begin{tabular}{|c|c|c|c|}
\hline Input indicator & Component 1 & Component 2 & Component 3 \\
\hline LQ & $\alpha_{11}^{\prime} \equiv \frac{\left|\alpha_{11}\right|}{C_{1}}$ & $\alpha_{12}^{\prime} \equiv \frac{\left|\alpha_{12}\right|}{C_{2}}$ & $\alpha_{13}^{\prime} \equiv \frac{\left|\alpha_{13}\right|}{C_{3}}$ \\
\hline $\mathrm{RP}$ & $\alpha_{21}^{\prime} \equiv \frac{\left|\alpha_{21}\right|}{C_{1}}$ & $\alpha_{22}^{\prime} \equiv \frac{\left|\alpha_{22}\right|}{C_{2}}$ & $\alpha_{23}^{\prime} \equiv \frac{\left|\alpha_{23}\right|}{C_{3}}$ \\
\hline $\mathrm{HHm}$ & $\alpha_{31}^{\prime} \equiv \frac{\left|\alpha_{31}\right|}{C_{1}}$ & $\alpha_{32}^{\prime} \equiv \frac{\left|\alpha_{32}\right|}{C_{2}}$ & $\alpha_{33}^{\prime} \equiv \frac{\left|\alpha_{33}\right|}{C_{3}}$ \\
\hline
\end{tabular}

Source: Crocco et al. (2006).

According to Crocco et al. (2006), observing that the $\alpha_{i j}^{\prime}$ of Table 4 represents the weights that each variable assumes within the components and that the eigenvalues ( $\beta_{i}$ of table 2 ) provide the data variance associated with the component, the final weight of each indicator is the result of the sum of the products of $\alpha^{\prime}{ }_{i j}$ by its corresponding eigenvalue for each component. Thus, Crocco et al. (2006) obtained Equations 9 to 11 as follows:

$\theta_{1}=\alpha^{\prime}{ }_{11} \beta_{1}+\alpha^{\prime}{ }_{12} \beta_{2}+\alpha^{\prime}{ }_{13} \beta_{3}$

$\theta_{2}=\alpha_{21}^{\prime} \beta_{1}+\alpha^{\prime}{ }_{22} \beta_{2}+\alpha_{23}^{\prime} \beta_{3}$

$\theta_{3}=\alpha_{31}^{\prime} \beta_{1}+\alpha_{32}^{\prime} \beta_{2}+\alpha_{33}^{\prime} \beta_{3}$

where

$\theta_{1}=$ weight of LQ; $\theta_{2}=$ weight of RP; $\theta_{3}=$ weight of $\mathrm{HHm}$.

The analysis can be easily verified by adding Equations 9, 10, and 11, as detailed below:

$$
\begin{aligned}
& \theta_{1}+\theta_{2}+\theta_{3}=\frac{\left|\alpha_{11}\right|}{C_{1}} * \beta_{1}+\frac{\left|\alpha_{21}\right|}{C_{1}} * \beta_{1}+\frac{\left|\alpha_{31}\right|}{C_{1}} * \beta_{1}+\frac{\left|\alpha_{12}\right|}{C_{2}} * \beta_{2}+\frac{\left|\alpha_{22}\right|}{C_{2}} * \beta_{2}+\frac{\left|\alpha_{32}\right|}{C_{2}} * \beta_{2} \\
& +\frac{\left|\alpha_{13}\right|}{C_{3}} * \beta_{3}+\frac{\left|\alpha_{23}\right|}{C_{3}} * \beta_{3}+\frac{\left|\alpha_{33}\right|}{C_{3}} * \beta_{3}=\frac{\beta_{1}}{C_{1}}\left(\left|\alpha_{11}\right|+\left|\alpha_{21}\right|+\left|\alpha_{31}\right|\right)+\frac{\beta_{2}}{C_{2}}\left(\left|\alpha_{12}\right|+\left|\alpha_{22}\right|+\left|\alpha_{32}\right|\right) \\
& +\frac{\beta_{3}}{C_{3}}\left(\left|\alpha_{13}\right|+\left|\alpha_{23}\right|+\left|\alpha_{33}\right|\right)=\beta_{1}+\beta_{2}+\beta_{3}=1
\end{aligned}
$$

The analysis allows estimating the relative weight of each variable (LQ, RP, HHm) in a single index, the normalized Concentration Index ( $\mathrm{nCl}$ ). According to Crocco et al. (2006), this index can evaluate the specificity of activity within a municipality (evaluated by LQ), the weight of this activity for the industrial structure of the municipality (measured with $\mathrm{HHm}$ ), the importance of the sector in the state (evaluated with RP). For the authors, with the combination of these three indices, the $\mathrm{nCl}$ evaluates the absolute scale of the local industrial structure.

\section{Impact of the sugarcane agroindustry in the state of Mato Grosso do Sul}

First, this item addresses the impact of sugarcane agroindustry on formal employment in the state of Mato Grosso do Sul before focusing on the impact on wages. 


\subsection{Impact on formal employment}

The $\mathrm{nCl}$ depends on the weight of the three indexes that compose it. The weight of all of the indices attributed to the sugarcane industry in the periods under analysis was similar, between 0.31 and 0.35 (variables $\theta_{i}$ of Equations 9 to 11). These results indicate that all indices have equivalent explanatory power in the $\mathrm{nCl}$ variance.

\subsubsection{Locational Quotient for formal employment}

In the analysis of formal jobs in the sugarcane industry, 17 municipalities had an LQ over 1 in 2014 (Table 5), which is considered specialized, and 15 had a result superior to 2. Among these municipalities, one had an LQ of over 19, two had an index higher than 9, and seven were higher than 4 (Table 5). The 15 municipalities with an LQ greater than 2 had at least one plant in operation, which proves the importance of a local production unit for the creation of formal jobs.

Table 5 - Historical LQ series of formal jobs in the sugarcane industry in Mato Grosso do Sul, for municipalities with LQs superior to 1 in 2014.

$\begin{array}{cccc}\text { Municipalities } & \mathbf{2 0 0 8} & \mathbf{2 0 1 0} & \mathbf{2 0 1 4} \\ \text { Angélica } & 20.58 & 16.47 & 19.16 \\ \text { Rio Brilhante } & 12.07 & 9.45 & 10.67 \\ \text { Nova Alvorada do Sul } & 6.57 & 9.31 & 9.38 \\ \text { Vicentina } & 7.99 & 4.25 & 5.69 \\ \text { Costa Rica } & 2.29 & 3.42 & 5.48 \\ \text { Caarapó } & 2.06 & 5.5 & 5.1 \\ \text { Maracaju } & 2.97 & 4.6 & 4.46 \\ \text { Bataiporã } & - & 2.7 & 4.32 \\ \text { Fátima do Sul } & 1.37 & 1.28 & 4.29 \\ \text { Eldorado } & 1.93 & - & 4.00 \\ \text { Naviraí } & 8,47 & 4,13 & 3,73 \\ \text { Chapadão do Sul } & 2,56 & 3,66 & 3,20 \\ \text { Nova Andradina } & - & 2,12 & 2,55 \\ \text { Sonora } & 10,42 & 11,26 & 2,18 \\ \text { Aparecida do Taboado } & 3,18 & 2,16 & 2,03 \\ \text { Anaurilândia } & - & - & 1,63 \\ \text { Ponta Porã } & - & 1,64 & 1,54\end{array}$

When comparing the evolution of LQs in the sugarcane industry during the period from 2008 to 2014, it is possible to consider that the sector is stable. Among the 15 municipalities with LQs higher than 2 in 2014, only two appeared in 2010 due to the beginning of the operation of plants in these municipalities.

One municipality had an LQ above 7 until 2010 and disappeared in 2014 due to the closure of the local sugarcane processing facility. Another municipality (Sonora) had an LQ higher than 10 and fell to 2 in 2014, with no apparent explanation.

The municipalities with sugarcane plantations, but with an LQ inferior to 1 are all municipalities without sugarcane agroindustry (Brasilândia, Sidrolândia, and Paranaíba), with only a small distillery (Iguatemi) or larger municipality with a lot of industrial activities (Dourados).

The 17 municipalities with an LQ superior to 1 represented $21.5 \%$ of the municipalities in the state. Almost all are small and essentially rural, not influencing the fact that the municipality is located in an area where livestock or soybeans predominate.

Because the state has few options for industrialization and formal employment, the results show the importance of the sugarcane industry for diversifying the economic matrix 
and inducing growth in the economy of small municipalities. The LQ evidenced the importance of the presence of a processing unit in the municipality. However, this index underestimates the importance of sugarcane in large municipalities with many activities, as in Dourados.

\subsubsection{Evaluation of the Relative Participation for formal employment}

We found seventeen municipalities with a share of at least $1 \%$ of the total jobs in the industry. In total, these municipalities concentrated $99 \%$ of the total employment of this industry in the state (Table 6). When considering the eight municipalities with a share of $5 \%$ or more, formal jobs related to sugarcane represented $79 \%$ of the jobs in the state, which indicates a large concentration in few municipalities.

Table 6 - Historical series of Relative Participation (RP) in the formal jobs in the sugarcane industry in Mato Grosso do Sul, by percentage, for municipalities with RPs superior to 1\% in 2014

$\begin{array}{cccc}\text { Municipalities } & \mathbf{2 0 0 8} & \mathbf{2 0 1 0} & \mathbf{2 0 1 4} \\ \text { Angélica } & 11 & 10 & 20 \\ \text { Rio Brilhante } & 17 & 16 & 17 \\ \text { Nova Alvorada do Sul } & 4 & 8 & 9 \\ \text { Dourados } & 10 & 12 & 9 \\ \text { Naviraí } & 21 & 8 & 7 \\ \text { Maracaju } & 4 & 7 & 5 \\ \text { Costa Rica } & 2 & 3 & 5 \\ \text { Caarapó } & 1 & 5 & 4 \\ \text { Chapadão do Sul } & 2 & 4 & 3 \\ \text { Nova Andradina } & - & 3 & 2 \\ \text { Ponta Porã } & - & 3 & 2 \\ \text { Aparecida do Taboado } & 3 & 2 & 2 \\ \text { Bataiporã } & - & 1 & 1 \\ \text { Fatima do Sul } & 1 & 1 & 1 \\ \text { Sonora } & 7 & 7 & 1 \\ \text { Vicentina } & 1 & 1 & - \\ \text { Eldorado } & 1 & - & \end{array}$

Among these eight municipalities, the RP decreased from $60 \%$ to $57 \%$ between 2008 and 2010 , before growing in the next period and reaching $70 \%$ in 2014 . These data indicate an increase of concentration in the state in the main producing municipalities.

The results of the RP were very similar to those of LQ, with the first three municipalities being the same in both indices. The difference comes from the fact that the RP is not influenced by the size of the municipality or the amount of activities present in this municipality. This index identified the municipality of Dourados as one of the largest for the sugarcane industry in the state, although the activity is not so important for this municipality, as identified by the low LQ.

\subsubsection{Evaluation of the Herfindahl-Hirschman modified index for formal employment}

The third index evaluated to measure the $\mathrm{nCl}$ was the $\mathrm{HHm}$. This index compares the $\mathrm{RP}$ of the activities related to sugarcane in the municipality with the RP of the other activities in the same municipality (OP).

It is possible to highlight two municipalities (Angélica and Rio Brilhante) where the RP exceeded OP by more than 10 percentage points (Table 7). In these municipalities, activities of the sugarcane industry were much more important than other activities. 
In the second group of five municipalities, the difference between RP and OP was four to eight percentage points (Table 7), which indicates the importance of the sugarcane industry. The third group, of nine municipalities, presented an $\mathrm{HHm}$ very close to zero. Although sugarcane was still important in these municipalities, this activity did not stand out much in formal jobs from other activities.

Dourados, the fifth municipality with the largest number of formal employees in the state, has a small $\mathrm{HHm}$ of 1 percent. Despite the importance of the sugarcane industry for formal jobs (high RP), this activity is not so important for the municipality (low LQ), and for the state, other activities encountered in Dourados are as important as sugarcane (low HHm).

Table 7 - Historical series of the HHm of formal jobs in the sugarcane industry of Mato Grosso do Sul, as a percentage, for municipalities with $\mathrm{HHms}$ superior to $1 \%$.

\begin{tabular}{cccc} 
Municipalities & $\mathbf{2 0 0 8}$ & $\mathbf{2 0 1 0}$ & $\mathbf{2 0 1 4}$ \\
Angélica & 10 & 10 & 19 \\
Rio Brilhante & 16 & 14 & 15 \\
Nova Alvorada do Sul & 4 & 7 & 8 \\
Naviraí & 18 & 6 & 5 \\
Maracaju & 2 & 5 & 4 \\
Costa Rica & 1 & 2 & 4 \\
Caarapó & 1 & 4 & 3 \\
Chapadão do Sul & 1 & 3 & 3 \\
Nova Andradina & - & 2 & 2 \\
Bataiporã & - & 1 & 1 \\
Sonora & 6 & 6 & 1 \\
Aparecida do Taboado & 2 & 1 & 1 \\
Ponta Porã & - & 1 & 1 \\
Dourados & - & 4 & 1 \\
Eldorado & - & - & 1 \\
Fatima do Sul & & - & 5 \\
\hline
\end{tabular}

When analyzing the historical context, it is possible to identify large variations, mainly between 2008 and 2010, with stability occurring in the later period. In most cases, the HHm increased because of plants opening in the municipalities, except in Naviraí, where there was a decrease. This municipality has one of the oldest production facilities in the state, which has undergone a process of judicial recovery and reduced the number of employees by more than $60 \%$.

\subsubsection{Evaluation of the $\mathrm{nCl}$ for formal employment}

The $\mathrm{nCl}$ results (Table 8) indicate that the three cities with the highest index are those with the three highest separated indexes (LQ, RP, and HHm). Together, they represent $18.74 \%$ of the total sugarcane area, $29.84 \%$ of production and $45.39 \%$ of the formal jobs of this industry in the state. It is important to emphasize a greater concentration of jobs in the area and production. In this group, sugarcane is of great importance for both the state and the municipality. 
Table $8-\mathrm{nCl}$ and other concentration indices of formal employment in the sugarcane industry of Mato Grosso do Sul, in 2014.

$\begin{array}{ccccc}\text { Municipalities } & \text { LQ } & \text { RP } & \text { HHm } & \mathbf{n C I} \\ \text { Angélica } & 19.16 & 0.20 & 0.19 & 1.00 \\ \text { Rio Brilhante } & 10.67 & 0.17 & 0.15 & 0.78 \\ \text { Nova Alvorada do Sul } & 9.38 & 0.09 & 0.08 & 0.59 \\ \text { Maracaju } & 4.46 & 0.07 & 0.05 & 0.44 \\ \text { Naviraí } & 3.73 & 0.07 & 0.05 & 0.44 \\ \text { Costa Rica } & 5.48 & 0.05 & 0.04 & 0.42 \\ \text { Caarapó } & 5.10 & 0.05 & 0.04 & 0.41 \\ \text { Dourados } & 0.88 & 0.09 & -0.01 & 0.38 \\ \text { Chapadão do Sul } & 3.2 & 0.04 & 0.03 & 0.35 \\ \text { Nova Andradina } & 2.55 & 0.04 & 0.03 & 0.35 \\ \text { Bataiporã } & 4.32 & 0.02 & 0.02 & 0.33 \\ \text { Vicentina } & 5.69 & 0.01 & - & 0.33 \\ \text { Fátima do Sul } & 4.29 & 0.02 & 0.01 & 0.33 \\ \text { Eldorado } & 4 & 0.01 & 0.01 & 0.32 \\ \text { Ponta Porã } & 1.54 & 0.03 & 0.01 & 0.30\end{array}$

In the second group, four municipalities presented an intermediate $\mathrm{nCl}$, between 0.4 and 0.5 , with the three indexes (LQ, RP, and $\mathrm{HHm}$ ) also occurring at high levels, although inferior to the three municipalities with the highest $\mathrm{nCl}$. In this group, sugarcane is also important for municipalities and the state, even if at a lower level than in the first group.

Among the municipalities that had $\mathrm{nCls}$ between 0.3 and 0.4 , Dourados presented a low LQ and HHm, but a high RP. This result can be explained by the great diversity in the economy of this municipality, which lessened the importance of the sugarcane industry for the municipality, even if Dourados accounted for $9 \%$ of the formal jobs of this industry.

The other municipalities, with $\mathrm{nCls}$ between 0.3 and 0.4 , exhibited high LQ and lower RP and $\mathrm{HHm}$. They are all small municipalities with few industry options. The sugarcane industry is very important for them because it represents the only industrial activity that generates formal jobs. Thus, even a small percentage of the state production may represent a high proportion of the formal jobs of the municipality. In this group, all the municipalities had at least one sugarcane facility in operation.

\subsection{Impact on wages}

All the concentration indices calculated for wages in the sugarcane industry were very similar to those obtained for formal jobs, so the analysis will not be separated for each type of index, as in section 4.1.

The LQ analysis of wages selected 17 municipalities with LQ higher than 1 in 2014, which were highly specialized. Among them, 9 had LQs higher than 4. This result is similar to the analysis of formal employment, changing only the classification of some municipalities.

When comparing the evolution of the LQ of wages, they increased in half of the municipalities between 2008 and 2010, indicating an implementation phase in these localities. As for formal employment, the sugarcane industry impacted wages mainly in municipalities that had processing facilities.

In an analysis of the RP of wages in the sugarcane industry in 2014, 17 municipalities with a share of at least $1 \%$ of the total wages in the sector were counted, and eight of them had RPs greater than $5 \%$. 
The municipalities with RPs greater than $1 \%$ concentrated $97.5 \%$ of the salaries from the sugarcane industry in 2014 in the state. The eight municipalities with RPs greater than, or equal to $5 \%$ accounted for $82 \%$ of Mato Grosso do Sul's wages from the sugarcane industry in the same period, which indicates a very large concentration of wages in this sector. This concentration was a little higher when compared to the one calculated for formal jobs.

In these eight municipalities, the RP increased from 69\% in 2008 to $72 \%$ in 2010 and $82 \%$ in 2014. These results indicate an increase in the concentration of the sugarcane industry income in the main producing municipalities.

In an analysis of $\mathrm{HHm}$ for wages in the sugarcane industry, two municipalities were highlighted. In these places, the RP of wages exceeded the OP by more than 10 percentage points, which is similar to the result obtained in the analysis of formal employment.

The results of the $\mathrm{nCl}$ for wages are similar to those obtained for formal jobs, which indicates a similar distribution between jobs and wages. The three groups identified remain the same, with no change in the group with $\mathrm{nCl}$ greater than 0.5 . This group is the most representative because it concentrates $49 \%$ of the wages of the sector in the state, against $46 \%$ of formal jobs.

In the intermediate group also appear the same municipalities, with the fall of Naviraí, that passed slightly below the limit of 0,4 . The fact that in this municipality the processing unit recently underwent a judicial recovery and reduced the number of employees can explain lower wages and consequently a lower $\mathrm{nCl}$.

In the third group, with $\mathrm{nCl}$ between 0.3 and 0.4 , a new municipality appeared, Aparecida do Taboado. In the $\mathrm{nCl}$ for wages, this municipality appears in the lower limit of the third group while for the $\mathrm{nCl}$ of formal employment it was located slightly outside this limit, with 0.29, a small difference between the two values (Table 9).

Table $9-\mathrm{nCl}$ and other concentration indices for wages as well as $\mathrm{nCl}$ of formal employment, in the sugarcane industry of Mato Grosso do Sul, in 2014.

\begin{tabular}{ccccccc}
\multirow{2}{*}{ Municipalities } & \multicolumn{4}{c}{ Wages } & & Formal employment \\
\cline { 2 - 4 } Angélica & LQ & RP & HHm & nCl & nCl \\
Rio Brilhante & 18,75 & 0,23 & 0,21 & 1,00 & 0.78 \\
Nova Alvorada do Sul & 11,61 & 0,17 & 0,16 & 0,76 & 0.59 \\
Costa Rica & 10,17 & 0,09 & 0,08 & 0,57 & 0.42 \\
Maracaju & 7,06 & 0,06 & 0,05 & 0,45 & 0.44 \\
Caarapó & 5,44 & 0,07 & 0,05 & 0,44 & 0.41 \\
Naviraí & 5,86 & 0,05 & 0,04 & 0,41 & 0.44 \\
Dourados & 3,66 & 0,06 & 0,04 & 0,39 & 0.38 \\
Fatima do Sul & - & 0,09 & - & 0,36 & 0.33 \\
Nova Andradina & 5,49 & 0,02 & 0,02 & 0,35 & 0.35 \\
Vicentina & 3,18 & 0,04 & 0,03 & 0,35 & 0.33 \\
Chapadão do Sul & 6,19 & 0,01 & - & 0,34 & 0.35 \\
Bataiporã & 3,27 & 0,04 & 0,03 & 0,34 & 0.33 \\
Aparecida do Taboado & 4,81 & 0,02 & 0,01 & 0,33 & 0,29 \\
Eldorado & 2,67 & 0,02 & 0,01 & 0,31 & 0.32 \\
Ponta Porã & 3,75 & 0,01 & 0,01 & 0,30 & 0.30
\end{tabular}

Among the municipalities with the highest concentrations of $\mathrm{nCl}$, only two exhibited growth after 2010 (Table 10). Most municipalities did not benefit from the strong growth of activity in the state, with jobs and wages concentrated in a few of them. 
Table 10 - Evolution of the $\mathrm{nCl}$ of wages in the municipalities of Mato Grosso do Sul for the sugarcane industry between 2008 and 2014, for municipalities with nCls superior to 0.4 in 2014.

\begin{tabular}{cccc} 
Municipalities & $\mathbf{2 0 0 8}$ & $\mathbf{2 0 1 0}$ & $\mathbf{2 0 1 4}$ \\
Angélica & 0.78 & 0.83 & 1.00 \\
Rio Brilhante & 0.89 & 0.88 & 0.76 \\
Nova Alvorada do Sul & 0.51 & 0.68 & 0.57 \\
Costa Rica & 0.31 & 0.40 & 0.45 \\
Maracaju & 0.36 & 0.55 & 0.44 \\
Caarapó & 0.35 & 0.51 & 0.41 \\
Naviraí & 0.75 & 0.55 & 0.39 \\
\hline
\end{tabular}

The rapid decrease of the $\mathrm{nCl}$ in the municipality of Navirai proves the reduction of wages linked to the situation of the company.

\section{Final considerations}

Expansion of sugarcane has allowed the installation of a large number of factories in Mato Grosso do Sul, which has led to the generation of employment and better wages for some municipalities in the state, mainly in agricultural regions.

For these municipalities, sugarcane is an important job and income generator, but the effect has been quite localized. The sector has experienced great growth in Mato Grosso do Sul between 2006 and 2014 when many factories were installed with high technology. As a result, the state did not suffer major impacts from the modernization of the crop because most of the companies have been installed with mechanized harvesting. In older facilities, the loss of jobs in the field was compensated for by the accelerated growth in the industry.

In Mato Grosso do Sul, the sugarcane industry experienced a high geographic concentration in terms of employment generation and salaries, with a focus in the central and southern parts of the state. The impact of formal employment was very strong in seven municipalities: Angélica, Rio Brilhante, Nova Alvorada do Sul, Maracaju, Naviraí, Costa Rica, and Caarapó, which represent $7.8 \%$ of the population of the state. In total, it had an impact on 18 municipalities, which together represent $25.6 \%$ of Mato Grosso do Sul population, including the municipality of Dourados, which alone corresponds to $8 \%$ of the state population. With the withdrawal of Dourados, which has greater economic diversification and does not depend on sugarcane, the 17 municipalities that depend most on this crop, as the main activity generating employment and wages, were equivalent to only $17.61 \%$ of the population of Mato Grosso do Sul. This proves the importance of sugarcane for the creation of formal jobs in a limited number of small municipalities.

Siqueira \& Castro Junior (2013) already identified similar positive aspects in the presence of sugarcane mills in certain Brazilian municipalities, such as job creation and higher wages, which reduce migration to urban areas, improving the quality of life. The authors also identified income and tax generation, as well as increased transfers of state resources to these municipalities.

Shikida \& Souza (2009) also found beneficial effects on the rural exodus and local commerce due to the implantation of a sugarcane mill in a small rural municipality. For the authors, the mill they surveyed had a positive impact on the number of people also engaged in other urban activities, such as commerce, logistics, social activities, public administration, among others. Although not evaluated in this paper, these benefits should also be present in Mato Grosso do Sul and further increase the impact of sugarcane.

Moraes et al. (2016) found a positive effect also for the municipalities neighboring those with industrial units for processing sugarcane. While a 10\% increase in the share of the area planted with sugarcane concerning the area planted with other temporary crops increased municipal GDP per capita of $76 \$$ in the municipality where the processing unit was installed, this GDP increased by an average of $31 \$$ in neighboring municipalities. 
The importance of sugarcane is much greater in small municipalities, where the labor market is limited, and the sugarcane industry represents almost the exclusive option for formal jobs. Belik et al. (2013) verified the importance of the sugarcane industry in these small municipalities. In regions with a strong presence of sugarcane, it represented more than half of the agricultural workers. For the authors, it was clear that changes in this labor market had a strong impact on the regional economy. These municipalities have become dependent on sugarcane processing facilities because other agricultural activities have almost no impact on the formal labor force. When a processing facility closes, the level of formal employment is greatly impaired and workers do not have alternatives in their relocation, as observed in some municipalities of Mato Grosso do Sul.

Shikida \& Souza (2009) and Siqueira \& Castro Junior (2013) also identified the risk for municipalities to depend on only one economic activity. For them, this dependence damages the economy of the municipality in case of a crisis.

The high level of average wages paid by the sugarcane industry is another factor responsible for the dynamism of small municipalities in Mato Grosso do Sul. Besides wages, another important factor is the formality of jobs. Large formalization in the sugarcane industry is relatively recent, as according to Moraes (2007) the proportion of formal employees rose from $40.7 \%$ in 1981 to $85.8 \%$ in 2005. In Mato Grosso do Sul, at the time of the research, this percentage was close to $100 \%$. This situation is confirmed by Siqueira \& Castro Junior (2013) who found greater formalization of employment in municipalities where sugarcane industries were established and by Toneto Junior \& Liboni (2008) for whom sugarcane has the highest formality of employment in agriculture.

However, higher wages and formality may be detrimental to other agricultural activities in the region, influencing production costs, mainly due to the increase in labor cost.

Among the other aspects related to the development of sugarcane that may harm the municipalities, Siqueira \& Castro Junior (2013) identified the disruption of local productive activities important for food supply and regional trade, threatened by the introduction of sugarcane monoculture on a large scale. However, Defante et al. (2018) disagree with this view. For the authors, the impact of sugarcane on food production has generated positive externalities for Mato Grosso do Sul, forcing the evolution of productivity. Food production has not reached its maximum productivity potential, as for cattle in Mato Grosso do Sul, the growth of biofuel production can increase food production and not the opposite.

The international crisis of 2008, as well as the Brazilian crisis of 2013/14, did not have much impact on the jobs and wages in the sugarcane industry in Mato Grosso do Sul. The companies in this sector cannot reduce their activities from one year to the next due to commitments from agricultural production or marketing contracts. Thus, they continue to work normally, even in a crisis. If this situation continues for a longer period, industries can reduce their activities and adapt to the new situation.

This situation is alarming due to the potential impact on small municipalities that produce sugarcane in the state. To reduce the impact of a crisis in the sugarcane industry, the best option is to encourage the diversification of activities in small municipalities. However, the only activities present in these municipalities are beef cattle and soy production. The relationship between these activities in Mato Grosso do Sul has already been evaluated by Defante et al. (2018) that identified a positive relationship between sugarcane production and the productivities of the two other activities, which, despite a decrease in area, increased production between 2008 and 2014. However, these productions have an impact essentially on rural labor. Further research should be carried out to verify their role in the recovery of the local economy of small rural municipalities in the event of a crisis in the sugarcane industry.

\section{REFERENCES}

Alexandratos, N., \& Bruinsma, J. (2012). World agriculture towards 2030/2050: the 2012 revision. Rome: FAO, Agricultural Development Economics Division. Retrieved in 2015 May 15, from www.fao.org/docrep/016/ap106e/ap106e.pdf 
Associação de Produtores de Bioenergia de Mato Grosso do Sul - BIOSUL. (2015). Setor sucroenergético gera empregos apesar da crise. Retrieved in 2015 June 14, from biosulms.com.br/noticias/industria/setor-sucroenergetico-gera-empregos-apesar-da-crise107.html

Audretsch, D. B., \& Feldman, M. P. (1996). R\&D spillovers and geography of innovation and production. The American Economic Review, 86(13), 630-640.

Baccarin, J. G., Gebara, J. J., \& Borges Junior, J. C. (2011). Expansão canavieira e ocupação formal em empresas sucroalcooleiras do Centro-Sul do Brasil, entre 2007 e 2009. Revista de Economia e Sociologia Rural, 49(2), 493-506.

Baer, C., \& Brown, T. (2006). Location quotients: a tool for comparing regional industry compositions. Incontext, 7(3), 1-3.

Belik, W., Perosa, B., \& Fredo, C. E. (2013). Dinâmica econômica e emprego nas regiões canavieiras no estado de São Paulo. In Anais do 37o Encontro Anual da ANPOCS (pp. 1-30). São Paulo: ANPOCS.

Brasil. Ministério do Trabalho e Emprego - MTE. (2015a). Cadastro Geral de Empregados e Desempregados (CAGED). Informações das Declarações fora do Prazo - CAGED. Brasília: MTE. Retrieved in 2015 July 25, from http://bi.mte.gov.br/bgcaged/caged_acerto/caged_acerto_basico_tabela.php

Brasil. Ministério do Trabalho e Emprego - MTE. (2015b). Relação Anual de Informações Sociais (RAIS). RAIS vínculo Id. Ano 2008, 2010, 2013, 2014. Brasília: MTE. Retrieved in 2015 July 25, from http://bi.mte.gov.br

Brasil. Ministério do Trabalho. (2016). Bases estatísticas RAIS e CAGED. Brasília: Programa de Disseminação das Estatísticas do Trabalho - PDET. Retrieved in 2016 December 15, from http://pdet.mte.gov.br/solicitacao-de-acesso-online.

Brito, S. R., Silva, A., Cruz, A. G., Monteiro, M. A., Vijaykumar, N. L., Silva, M. S., Costa, J. C. W. A., \& Francês, C. R. L. (2016). Concentration of access to information and communication technologies in the Municipalities of the Brazilian Legal Amazon. PLoS One, 11(4), e0152655. http://dx.doi.org/10.1371/journal.pone.0152655

Centenaro, M. (2012). Um estudo sobre investimento direto externo no setor sucroenergético do estado de Mato Grosso do Sul (Tese de doutorado). Programa de Pós-graduação em Administração, Universidade do Vale do Rio dos Sinos, São Leopoldo.

Cezarino, L. O., \& Liboni, L. B. (2012). Social and environmental impacts of the sugarcane industry. Future Studies Research Journal, 4(1), 202-230.

Chiang, S. H. (2009). Location quotient and trade. The Annals of Regional Science, 43, 399-414. http://dx.doi.org/10.1007/s00168-008-0218-y

Companhia Nacional de Abastecimento - CONAB. (2016a). Acompanhamento da safra brasileira: cana-deaçúcar. (Vol. 3 - Safra 2016/17, N² 2 - Segundo Levantamento). Brasília: CONAB. Retrieved in 2017 January 17 , from http://www.conab.gov.br/OlalaCMS/uploads/arquivos/16_08_17_10_07_35_boletim_cana_portugue s_-_2o_lev_-_16-17.pdf

Companhia Nacional de Abastecimento - CONAB. (2016b). Série histórica de áreas plantadas com canade-açúcar, safras 2005/06 a 2015/16 em mil hectares. Brasília: CONAB. Retrieved in 2017 January 17, from www.conab.gov.br/conteudos.php?a=1252\&t=2\&Pagina_objcmsconteudos=2\#A_objcmsconteudos

Crawley, A., Beynon, M., \& Munday, M. (2013). Making locational quotients more relevant as a policy aid in regional spatial analysis. Urban Studies (Edinburgh, Scotland), 50(9), 1854-1869. http://dx.doi.org/10.1177/0042098012466601

Crocco, M. A., Galinari, R., Santos, F., Lemos, M. B., \& Simões, R. (2006). Metodologia de identificação de aglomerações produtivas locais. Nova Economia, 16(2), 211-241.

De Propris, L. (2005). Mapping local production systems in the UK: methodology and application. Regional Studies, 39(2), 197-211. http://dx.doi.org/10.1080/003434005200059983

Defante, L. R., Vilpoux, O. F., \& Sauer, L. (2018). Rapid expansion of sugarcane crop for biofuels and influence on food production in the first producing region of Brazil. Food Policy, 79(1), 121-131. http://dx.doi.org/10.1016/j.foodpol.2018.06.005

Fingleton, B., Igliori, D. C., \& Moore, B. (2004). Employment growth of small high-technology firms and the role of horizontal clustering: evidence from computing services and R\&D in great Britain, 19912000. Urban Studies (Edinburgh, Scotland), 41(4), 773-799.

Food and Agriculture Organization of the United Nations - FAO. (2016). FAOSTAT data. Rome: FAO. 
Gallardo, A. L. C. F., \& Bond, A. (2011). Capturing the implications of land use change in Brazil through environmental assessment: Time for a strategic approach? Environmental Impact Assessment Review, 31(3), 261-270. http://dx.doi.org/10.1016/j.eiar.2010.06.002

Garcia, J. R. (2014). Trabalho rural: tendências em face das transformações em curso. In A. M. Buainain, E. Alves, J.M. da Silveira \& Z. Navarro . (Eds.), O mundo rural no Brasil do século 21: a formação de um novo padrão agrário e agrícola. Brasília, DF: Embrapa.

Goldemberg, J. (2008). The Brazilian biofuels industry. Biotechnology for Biofuels, 1(6), 1-7. http://dx.doi.org/10.1186/1754-6834-1-6

Instituto Brasileiro de Geografia e Estatística - IBGE. (2016). Cidades. Mato Grosso do Sul. Rio de Janeiro: IBGE Retrieved in 2016 January 28, from www.cidades.ibge.gov.br/xtras/uf.php?lang=\&coduf=50\&search=mato-grosso-do- sul

Krugman, P. (1991). Geography and trade. Cambridge: MIT Press.

Mendonça, M. L., Pitta, F. T., \& Xavier, C. V. (2012). A agroindústria canavieira e a crise econômica mundial. São Paulo: Rede Social de Justiça e Direitos Humanos.

Moraes, M. A. F. D. (2007). O mercado de trabalho da agroindústria canavieira: desafios e oportunidades. Economia Aplicada, 11(4), 605-619.

Moraes, M. A. F. D., Bacchi, M. R. P., \& Caldarelli, C. E. (2016). Accelerated growth of the sugarcane, sugar, and ethanol sectors in Brazil (2000-2008): effects on municipal gross domestic product per capita in the south-central region. Biomass and Bioenergy, 91, 116-125.

Neves, M. F., Kalaki, R. B., Trombin, V. G., \& Rodrigues, J. M. (2016). Sugarcane industry development analysis from the perspective of agro-industrial system quantification. Research in Agriculture, 1(2), 42-57. http://dx.doi.org/10.22158/ra.v1n2p42

Neves, M. F., Trombin, V. G., \& Consoli, M. A. (2010). Measurement of sugar cane chain in Brazil. The International Food and Agribusiness Management Review, 13(3), 37-54.

Oliveira, C. M., Auad, A. M., Mendes, S. M., \& Frizzas, M. R. (2014). Crop losses and the economic impact of insect pests on Brazilian agriculture. Crop Protection (Guildford, Surrey), 56, 50-54. http://dx.doi.org/10.1016/j.cropro.2013.10.022

Paiva, W. L., \& Khan, A. S. (2011). Dependência espacial e emprego formal: o que é possível afirmar para indústria cearense? (pp. 1-20). Fortaleza: IPECE. Retrieved in 2014 March 11, from www.repositorio.ufc.br/bitstream/riufc/5200/1/2011_capliv_askhan.pdf

Popp, J., Lakner, Z., Harangi-Rákos, M., \& Fári, M. (2014). The effect of bioenergy expansion: Food, energy, and environment. Renewable \& Sustainable Energy Reviews, 32, 559-578. http://dx.doi.org/10.1016/j.rser.2014.01.056

Resende, G. (2016). Álcool e açúcar: setor em expansão. Dourados: O Progresso. Retrieved in 2015 October 12, from www.progresso.com.br/opiniao/geraldo-resende/alcool-e-acucar-setor-emexpansao

Sentz, R. (2011). Understanding location quotient. USA: Emsi. Retrieved in 2017 March 4, from www.economicmodeling.com/2011/10/14/understanding-location-quotient-2/

Shikida, P. F. A., \& Souza, E. C. (2009). Agroindústria canavieira e crescimento econômico local. Revista de Economia e Sociologia Rural, 47(3), 569-600.

Siqueira, P. H. L., \& Castro Junior, L. G. (2013). Determinantes da localização da agroindústria canavieira nos municípios de Minas Gerais. Revista de Economia e Sociologia Rural, 51(2), 309-330.

Toneto Junior, R., \& Liboni, L. B. (2008). Evolução recente do mercado de trabalho da cana-de-açúcar no brasil (1995-2006). Organ. Rurais Agroindustriais, 10(3), 455-474.

União da Industria de Cana de Açúcar - UNICA. (2015). Sugarcane, one plant, many solutions: sugar, ethanol, bioelectricity \& beyond. São Paulo: UNICA. Retrieved in 2017 April 19, from http://english.unica.com.br/download.php?idSecao=17\&id=19441218

União da Industria de Cana de Açúcar - UNICA. (2016). UNICADATA - Production data - Sugarcane Planted area, 2005-2015. São Paulo: UNICA. Retrieved in 2017 April 17, from http://www.unicadata.com.br/historico-de-area-

ibge.php?idMn=33\&tipoHistorico=5\&acao=visualizar\&idTabela=1784\&produto=Planted + area\&anol $\mathrm{ni}=2005 \&$ anoFim $=2015 \&$ estado=MS

Vian, C. E. F. (2002). Inércia e Mudança Institucional: estratégias competitivas do complexo agroindustrial canavieiro no centro-sul do Brasil (Tese de doutorado). Universidade Estadual de Campinas. Instituto de Economia, Campinas. 
Vian, C. E. F. (2006). Complexo Agroindustrial Canavieiro - Análise do processo de evolução e consolidação tecnológica de 1930 a 2000: Implicações para a estruturação e dinâmica dos Campos Organizações no Complexo Agroindustrial Canavieiro (Série Pesquisa no P-58). Piracicaba: Esalq, USP.

Vian, C. E. F., \& Belik, W. (2003). Os desafios para a reestruturação do complexo agroindustrial canavieiro do Centro-Sul. Economía, 4(1), 153-194.

Vieira, M. C. A. (2007). Setor sucroalcooleiro brasileiro: evolução e perspectivas. Retrieved in 2019 January 15 , from https://www.bndes.gov.br/SiteBNDES/export/sites/default/bndes_pt/Galerias/Arquivos/conhecime nto/liv_perspectivas/07.pdf

Vital, A. (2015). Em busca da produtividade perdida. Interview with President of Biosul - Roberto Hollanda. Revista Canavieiros, 110, Retrieved in 2017 April 17, from https://www.revistacanavieiros.com.br/em-busca-da-produtividade-perdida

Waack, R. S., \& Neves, M. F. (1998). Competitividade do sistema agroindustrial da cana-de-açúcar. In E. M. M. Q. Farina \& D. Zylbersztajn. Competividade no Agribusiness Brasileiro (Vol. V). São Paulo: PENSA/FIA/FEA/USP.

Walter, A., Galdos, M. V., Scarpare, F. V., Leal, M. R. L. V., Seabra, J. E. A., Cunha, M. P., Picoli, M. C. A., \& Oliveira, C. O. F. (2014). Brazilian sugarcane ethanol: developments so far and challenges for the future. WIREs Energy Environ., 3, 70-92. http://dx.doi.org/10.1002/wene.87

Wilkinson, J. (2015). The Brazilian Sugar Alcohol Sector in the current national and international conjuncture. ActionAid Brasil. Retrieved in 2017 March 5, from www.actionaid.org.br/sites/files/actionaid/completo_sugar_cane_sector_ing.pdf 